\title{
Isolation and characterization of pigment deficient insertional mutants in the chlorophyte Chlamydomonas reinhardtii
}

\author{
Marta Vila' ${ }^{1}$ Encarnación Díaz-Santos ${ }^{1}$, Marta de la Vega ${ }^{1}$, Inma Couso ${ }^{2}$ and Rosa León ${ }^{1 *}$ \\ *Correspondence: rleon@uhu.es \\ 'Biochemistry and Molecular Biology Laboratory. Experimental Science Faculty, University of Huelva, Avda. Fuerzas Armadas s/n, \\ 21007-Huelva, Spain. \\ ${ }^{2}$ Institute of Plant Biochemistry and Photosynthesis, CIC Cartuja, University of Seville and CSIC, Avda. Américo Vespucio no. 49, \\ 41092-Seville, Spain.
}

\begin{abstract}
In the present work, a large collection of mutants was obtained by insertional mutagenesis from 704 (cw15 Arg7+ Nia1 : Ars $\mathrm{mt}+$ ) strain of Chlamydomonas reinhardtii, using a linearized fragment of the pSI03 plasmid. About 2100 insertional mutants resistant to the antibiotic paromomycin were isolated and screened to identify Chlamydomonas reinhardtii mutants: i) sensitive to high light, ii) with an altered pigment composition and iii) with an irregular response to high light stress. The insertion site in 15 of the selected mutants was amplified by Restriction enzyme site-directed amplification (RESDA) PCR or inverse PCR. Cloning, sequencing and alignment of the amplified DNA with the Chlamydomonas database allowed the identification of the region adjacent to the insertion in most of the mutants studied. We observed that in $77 \%$ of the transformants analysed, insertion took place in intragenic regions. Almost half of the mutants (46\%) had insertions in genome loci with unknown functions. Among disrupted genes with known functions, we found genes involved in a great diversity of functions, from flagella motion to regulatory or signal transduction processes, suggesting that the sensitivity to high light and the synthesis of pigments are complex and very regulated processes.

Keywords: Carotenoids, Chlamydomonas reinhardtii, microalgae, mutagenesis, pigments, zeaxanthin
\end{abstract}

\section{Introduction}

The unicellular green alga Chlamydomonas reinhardtii has become, during the last decades, a popular model system to understand gene functions due to its molecular, genetic and physiological features together with the availability of easy methods for its stable genetic transformation and the existence of complete genomic and cDNA (Complementary Deoxyribonucleic Acid ) databases [1,2]. Its role as a model system is particularly important to study photosynthesis and responses to light [3-5] due to the possibility of Chlamydomonas to grow either photoautotrophically in mineral media and light or heterotrophically in acetate and dark. The study of Chlamydomonas pigment-less mutants generated by traditional mutagenesis has offered interesting information about photoprotective mechanisms in microalgae and plants [4], but the identification of the gene affected in these kinds of mutants is not easy.

In the recent years, new approaches to generate mutants and understand gene function in microalgae and higher plants, in which homologous recombination does not occur at a high frecuency, have been developed [6].

Among reverse genetic approaches, developed to generate point mutations in specific genes: the use of zinc-finger nucleases, which allows the generation of small delections and/or insertions within the gene of interest through customdesigned chimeric endonucleases [7] and TILLING (Targeting Induced Local Lesions In Genomes), which combines traditional chemical mutagenesis with rapid mutational screening to discover induced lesions [8,9], are commonly used in plants but their high cost and laboriousness have limited their use in microalgas [10].

RNA silencing technique has been successfully used to suppress endogenous transcript levels in Chlamydomonas [11-13] but it is difficult to obtain a complete loss-of-function RNA-silenced strain and there may be off-target effects induced by the introduced construct $[6,10]$.

Exploring indexed insertional mutant libraries by PCR has been a popular approach to isolate strains with lesions in specific target genes in higher plants. A similar collection of mutants has been stablished for Chlamydomonas reinhardtii but maintenance of a collection of microalgal mutants is not easy [6].

On the contrary, forward genetic approaches allow the isolation of insertional mutants with specific phenotypes, which can be analysed by several easy methods to identify the gene affected, and have demonstrated to be a powerful tool to study the relationship existing between a gene sequence and its function in plant and microalgal cells. The technique is based on nuclear transformation of the microalga with an exogenous DNA marker, which is randomly integrated into the genome. After screening for a particular phenotype and analysis of the disrupted genes, it is possible to establish a functional relation between the affected gene and the phenotype selected. This approach has allowed isolation of mutants affected in 
Vila et al. Genomics Discovery 2013,

different metabolic and physiological aspects [14] and has become a popular method for forward genetics studies because identification of the affected genomic region is generally easier than location of genomic lesions caused by traditional mutagenesis procedures based on chemical or physical agents. In C. reinhardtii, this technique has allowed the isolation of mutants affected in flagellar function [15], phototaxis [16], microtubules [17], carbon assimilation [18], $\mathrm{H}_{2}$ production [19], photosynthesis [20], nitrogen [21] and sulphur metabolism [22].

The most complete functional genomic analysis of photosynthesis in Chlamydomonas by insertional mutagenesis was carried out by Dent and Coworkers [20]. They introduced a linearized plasmid carrying the ble gene from Streptoalloteicus hindustanus that confers resistance to bleomicin [23] and generated 2760 insertional mutants that were screened for light sensitive and nonphotosynthetic phenotypes. They characterized the insertion site in 50 of the isolated mutants, finding mutants affected in very diverse metabolic, physiological and regulatory genes.

In the present work, using a linerized fragment of the pSI03 plasmid [24], 2100 insertional mutants resistant to the antibiotic paromomycin have been isolated and screened to identify Chlamydomonas reinhardtii light-sensitive and pigment-deficient mutants. Mutants which have higher violaxanthin content (B20), higher pigments concentration (A7), lower chlorophyll content (C13) and total lack of chlorophylls and carotenoids (C2), together with three mutants that synthesize small quantities of zeaxanthin in response to high light stress (Z7, Z34 and Z198), have been isolated and physiologically characterized. The insertion site in 15 of the selected mutants has been characterized by RESDA PCR (Polymerase Chain Reaction) [25] or inverse-nested PCR [26], contributing to increase the information generated by previous photosynthetic functional genomic analysis in Chlamydomonas [20].

\section{Methods}

\section{Microorganisms and culture conditions}

Chlamydomonas reinhardtii cell-wall deficient strain 704 (Cw15, Arg7, $\mathrm{mt}+$ ) was kindly provided by Dr. Roland Loppes [27] and cultured photomixotrophically in liquid or agar solidified TAP (Tris-Acetate-Phosphate) medium [2] at $25^{\circ} \mathrm{C}$ under continuous white light irradiation of $100 \mathrm{\mu E} \mathrm{m}^{-2} \mathrm{~s}^{-1}$, unless other intensity is indicated. Light sensitive mutants obtained were kept in the dark or very low light intensity $\left(15 \mu \mathrm{E} \mathrm{m} \mathrm{m}^{-2}\right.$ $\left.\mathrm{s}^{-1}\right)$. The Escherichia coli strain used for in vivo amplification of DNA was DH5a, cultured in LB (Luria Broth) medium as previously described [28].

\section{High irradiance treatment}

For high irradiance experiments Chlamydomonas reinhardtii cultured in TAP plates were illuminated with an adjustable halogen lamp (Philips $500 \mathrm{~W}$ ). The plates were located under a glass thermostatic bath, connected with a refrigerated circulator (LAUDA E300), with water at a constant temperature of $25^{\circ} \mathrm{C}$ to avoid overheating of the plates. Light intensity was measured by a Delta OHM quantum photo radiometer equipped with a PAR sensor.

\section{Generation of insertional mutants in Chlamydomonas reinhardtii}

Insertional mutants were generated by transformation of the C. reinhardtii strain 704 (Cw15, Arg7, mt+) with a fragment of the plasmid pSI103 [24] which harbours the AphVIII gene from Streptomyces rimosus, coding for an aminoglycoside 3 'phosphotransferase that confers resistance to the antibiotic paromomycin, under the control of the strong constitutive promoters RbcS2 (Ribulose Bisphosphate Carboxylase Small Subunit 2) and Hsp70A (Heat Shock Protein 70A) and terminated by the $3^{\prime}$ untranslated region of $R b c S 2$. The fragment was exscinded from plasmid pSI103 by digestion with the endonucleases enzymes Notl and Kpnl (Figure 1.1).

\section{Nuclear transformation of Chlamydomonas reinhardtii} Transformation was carried out using the glass-bead method of Kindle [29] with minor modifications. C. reinhardtii cells were grown to a cell density of about $10^{7}$ cells per $\mathrm{ml}$, harvested by centrifugation and resuspended in fresh TAP medium to obtain a 100 fold concentrated cell suspension. The concentrated cell suspension $(0.6 \mathrm{ml})$ was added to a conical tube containing $0.3 \mathrm{~g}$ of sterile glass beads (0.4-0.6 mm diameter), $0.2 \mathrm{ml}$ of $20 \%$ polyethylene glycol (MW8000) and about $100 \mathrm{ng}$ of the desired plasmid. Cells were vortexed for $8 \mathrm{~s}$, resuspended in $50 \mathrm{ml}$ of fresh sterile TAP medium and incubated at dim light overnight. After this incubation in the absence of antibiotic, the cells were pelleted and spread onto TAP solid medium plates with paramomycin $\left(30 \mathrm{\mu g} \mathrm{ml}^{-1}\right)$. Transformed colonies will be visible after 4 or 5 days.

\section{Screening of light sensitive and pigment deficient mutants}

Transformed cells showing resistance to paromomycin were inoculated in $5 \mathrm{ml}$ of TAP liquid medium with paromomycin $\left(15 \mathrm{mg} \mathrm{ml}^{-1}\right)$ and grown under dim light as described in Microorganisms and culture conditions for 5 days. The absorbance at $660 \mathrm{~nm}$ was estimated and adjusted to the same optical density at $660\left(\mathrm{OD}_{660}\right)$ in all the cultures by adding fresh sterile TAP medium. $5 \mathrm{ml}$ of each culture were collected by centrifugation ( $1200 \times \mathrm{g}, 5 \mathrm{~min}$ ) and resuspended in $200 \mu \mathrm{l}$ of TAP medium. Two TAP-paromomycin plates were symmetrically spotted in an order array with $20 \mu \mathrm{l}$-drops of each culture and subjected to a two-step screening strategy. In the first screening step one replicate was kept at dim light $\left(100 \mu \mathrm{E} \mathrm{m}^{-2} \mathrm{~s}^{-1}\right)$ and the other was exposed to high light intensity $\left(800 \mu \mathrm{E} \mathrm{m}^{-2} \mathrm{~s}^{-1}\right)$. After two days, the growth of the transformants in each plate was evaluated (Figure 2). The mutants which died, grew more slowly than the control or 


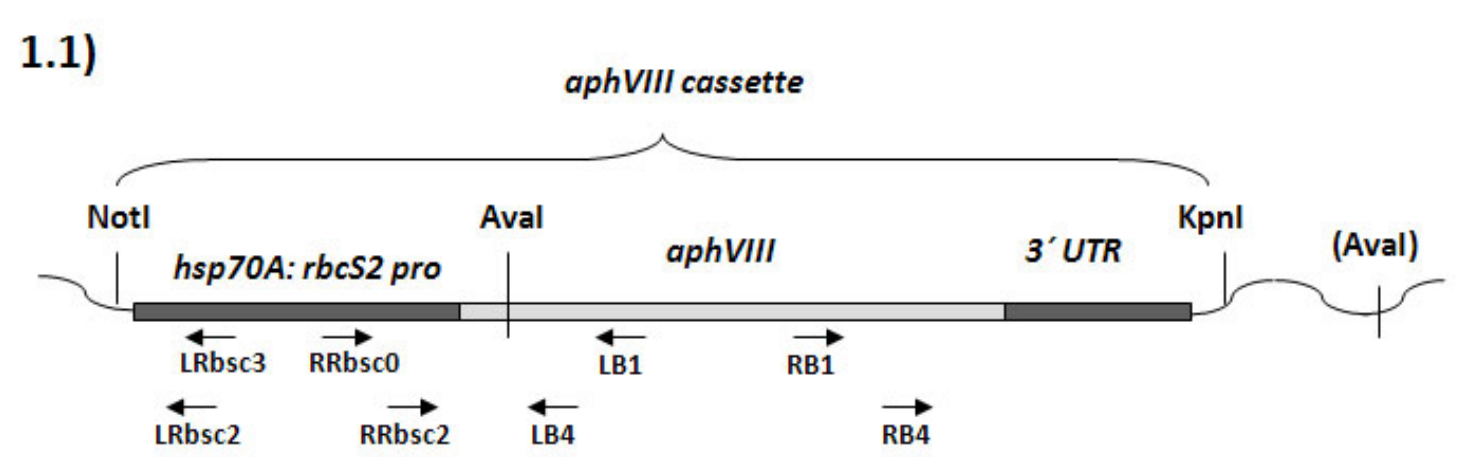

\section{2)}

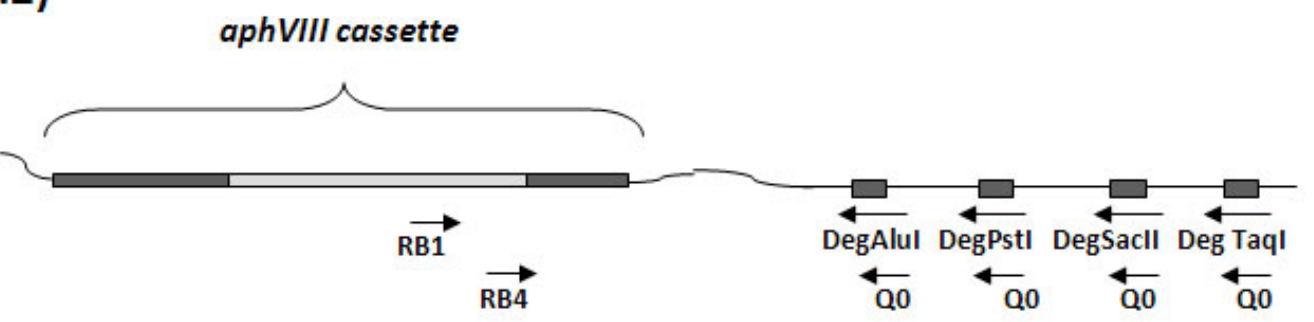

Figure 1. Schematic representation of the AphVIII cassette used for generation of insertional mutants. Primers annealing-sites used for amplification of the genomic regions flanking the insertion, both by inverse PCR (1) and RESDA PCR (2), are inducated. The sequence of these primers is shown in Table I.
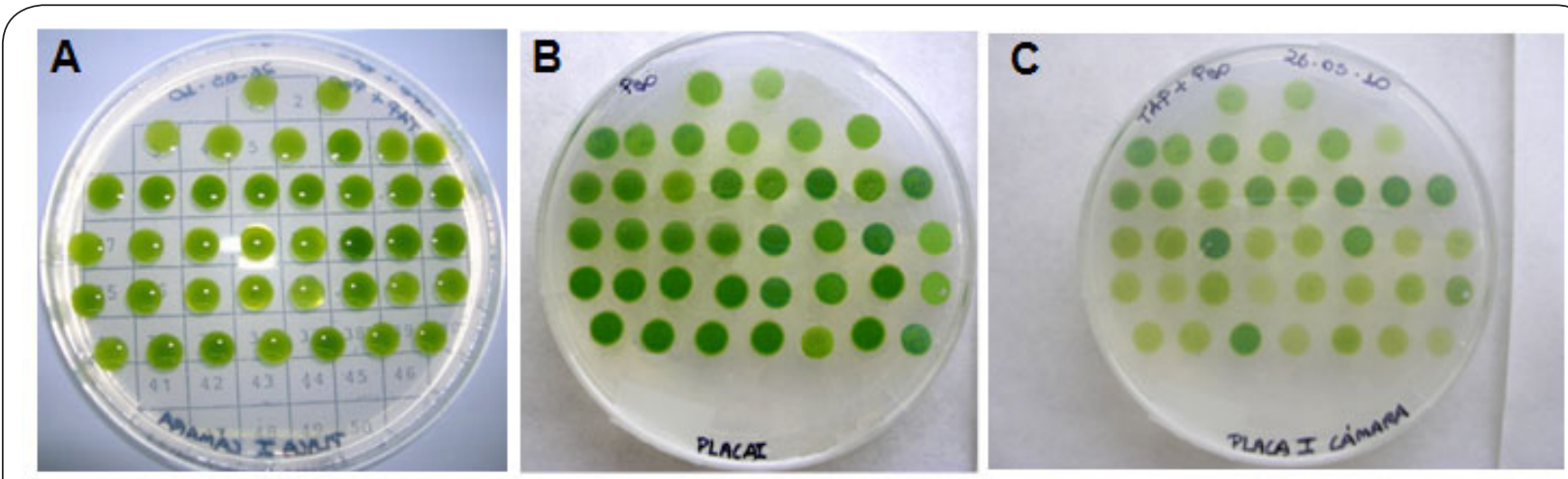

Figure 2. Screening of high light sensitive transformants. Drops of the well grown paromomycin resistant transformant cultures were symmetrically spotted on two plates in an order array (A). One replicate was kept at dim light and the other was exposed to high light intensity $\left(800 \mu \mathrm{E} \mathrm{m}^{-2} \mathrm{~s}^{-1}\right)$. After two days, the growth of each transformant at dim light (B) and at high light intensity (C) was evaluated.

showed deficient pigmentation were selected as high lightsensitive mutants. In the second step, light sensitive selected lines were cultured in TAP liquid medium with paromomycin $\left(15 \mu \mathrm{g} \mathrm{m}^{-1}\right)$ at low light intensity $\left(15 \mu \mathrm{E} \mathrm{m}^{-2} \mathrm{~s}^{-1}\right)$ and pigment composition of each selected mutant was chromatographically determined as described in Analysis of pigments.

Screening of mutants deficient in zeaxanthin synthesis in response to high light

Transform-cells showing resistance to paromomycin were inoculated in $5 \mathrm{ml}$ of TAP liquid medium $\left(15 \mathrm{\mu g} \mathrm{ml}^{-1}\right)$ and grown at standard conditions for 5 days. The volume in each tube was adjusted with fresh sterile TAP medium to obtain the same absorbance at $660 \mathrm{~nm}$ in all the tubes. Then, the cultures were subjected to a $24 \mathrm{~h}$ dark pre-treatment and immediately transferred to high light $\left(800 \mu \mathrm{E} \mathrm{m}^{-2} \mathrm{~s}^{-1}\right)$ for 2 $h$. The concentration of violaxanthin, anteraxanthin and zeaxanthin in each transformant was chromatographically determined as described in Analysis of pigments and the de-epoxidation state calculated as the ratio [(ant + zea) / 
Vila et al. Genomics Discovery 2013,

http://www.hoajonline.com/journals/pdf/2052-7993-1-2.pdf

doi: 10.7243/2052-7993-1-2

Table I. Primers used.

\begin{tabular}{|c|c|c|}
\hline Primer & Sequence $\left(5^{\prime}---3^{\prime}\right)$ & Uses \\
\hline NRfor & GCGCTGCCCTCCGTCACCTTCC & \multirow[t]{2}{*}{ Estimation of the number of $N R$ genes by qPCR } \\
\hline NRre & CAGCCGCACGCCCGTCCAGTAG & \\
\hline Parafor & GAGGATCTGGACGAGGAGCGGAA & \multirow{2}{*}{$\begin{array}{l}\text { Estimation of the number of AphVIII genes by qPCR } \\
\text { genes }\end{array}$} \\
\hline Pararev & CCCTCAGAAGAACTCGTCCAACAGC & \\
\hline RB1 & AGCTGGCCCACGAGGAGGAC & \multirow{4}{*}{$\begin{array}{l}\text { Identification of the region adjacent to the marker gene } \\
\text { by iPCR ( } 3 \text { ' end) }\end{array}$} \\
\hline LB1 & CCAGAGCTGCCACCTTGACA & \\
\hline RB4 & TGGTTCGGGCCGGAGTGTTC & \\
\hline LB3 & CCACCACCCCGAAGCCGATAA & \\
\hline $\mathrm{Rbsc} 0$ & CCCTCCCCGGTGCTGAAGAAT & \multirow{4}{*}{$\begin{array}{l}\text { Identification of the region adjacent to the marker gene } \\
\text { by iPCR ( } 5 \text { ' end) }\end{array}$} \\
\hline LRbsc3 & GTCGCGTATGTATAAGTGCTCGTTTG & \\
\hline Rbsc2 & CCGGTTGTGAGTGGGTTGTTGT & \\
\hline LRbsc2 & CGTTCGGGGTCGCGGGCTTTTA & \\
\hline RB1 & AGCTGGCCCACGAGGAGGAC & \multirow{7}{*}{$\begin{array}{l}\text { Identification of the region adjacent to the marker gene } \\
\text { by RESDA }\end{array}$} \\
\hline Deg Alu & CCAGTGAGCAGAGTGACGIIIIINNSWCAGCTT & \\
\hline Deg PstI & CCAGTGAGCAGAGTGACGIIIIINNSWCAGCTT & \\
\hline Deg SacII & CCAGTGAGCAGAGTGACGIIIIINNSCTGCAGW & \\
\hline Deg TaqI & CCAGTGAGCAGAGTGACGIIIIINNSCCGCGGW & \\
\hline RB4 & TGGTTCGGGCCGGAGTGTTC & \\
\hline Q0 & CCAGTGAGCAGAGTGACG & \\
\hline
\end{tabular}

(ant + zea + viol)] Those that showed a de-epoxidation state significantly lower than the control cells submitted to the same treatment were selected and rescreened in the same way two additional times.

\section{Small scale genomic DNA extraction}

The pellet obtained after centrifugation of $2 \mathrm{ml}$ of $C$. reinhardtii culture was resuspended in $300 \mu$ l of lysis buffer $(10 \mathrm{mM}$ Tris$\mathrm{HCl}, \mathrm{pH}$ 8.0, $1 \mathrm{mM}$ ethylenediaminetetraacetic acid (EDTA), $3 \%$ dodecilsulfato sódico (SDS) vortexed during $5 \mathrm{~min}$ and incubated at $4{ }^{\circ} \mathrm{C}$ for $5 \mathrm{~min}$. DNA was extracted with phenol/ chloroform and precipitated with ethanol absolute at $-20^{\circ} \mathrm{C}$ for 3-4 $\mathrm{h}$. The pellet was washed with ethanol $70 \%$, dried and resuspended in $5 \mathrm{mM}$ Tris- $\mathrm{HCl}, \mathrm{pH}$ 8. The genomic DNA suspension $(1 \mu \mathrm{l})$ was used to carry out the PCR reaction.

\section{Standard polymerase chain reaction}

The PCR amplification was performed from $1 \mu \mathrm{l}$ of genomic DNA in a total volume of $25 \mu \mathrm{l}$ containing $10 \mathrm{pmol}$ of each primer, $0.2 \mathrm{mM}$ desoxirribonucleotids (dNTPs), 0.5 U Taq DNA polymerase from Biotools (B\&M Labs, Madrid, Spain), $2.5 \mu \mathrm{l}$ of specific $10 \mathrm{X}$ buffer (containing $2.5 \mathrm{mM} \mathrm{MgCl}_{2}$ ), and $1 \%$ dimethylsulfoxide (DMSO). The PCR program was: $0.5 \mathrm{~min}$ at $96^{\circ} \mathrm{C}, 0.5 \mathrm{~min}$ at annealing temperature, and the required time at $72^{\circ} \mathrm{C}$ for 30 cycles.

\section{Inverse PCR}

Inverse PCR was preformed by digesting $500 \mathrm{ng}$ of genomic DNA with the restriction endonuclease $A v a l$, which has a unique restriction site inside the cassette used in the insertional mutagenesis experiments and has a high number of target sites in the genome of Chlamydomonas. The resulted digestions were precipitated by adding ethanol $95 \%$ and 3 $\mathrm{M}$ sodium acetate and incubation for $1-2 \mathrm{~h}$ at $-20^{\circ} \mathrm{C}$, washed with ethanol $70 \%$ and ligated with T4 ligase. The ligation was used as a template for nested PCR using different pairs of inverted primers (Table I). Each PCR reaction was carried out at the standard conditions described in Standard polymerase chain reaction, excepting that cycling conditions were $1 \mathrm{x}$ $\left(96{ }^{\circ} \mathrm{C}, 5 \mathrm{~min}\right) 35 \mathrm{x}\left(95^{\circ} \mathrm{C}, 1 \mathrm{~min} ; 60^{\circ} \mathrm{C}, 1 \mathrm{~min} ; 72^{\circ} \mathrm{C}, 3 \mathrm{~min}\right) 1 \mathrm{x}$ $\left(72^{\circ} \mathrm{C}, 10 \mathrm{~min}\right)$.

\section{RESDA PCR}

Restriction enzyme site-directed amplification PCR [25], RESDA-PCR, is modified from Thermal asymmetric interlaced TAIL-PCR [31] and basically involves using specific primers for the marker gene together with degenerated primers. The design of these degenerated primers is based on the presence of frequent restriction sites randomly distributed in the microalgal genome. The degenerated primer consists of the chosen restriction site with several highly degenerated nucleotides in the $3^{\prime}$ end linked by a polyinosine bridge to a specific Qo sequence in the $5^{\prime}$ end (see Figure 1.2). Two amplification rounds at the cycling conditions indicated below, allowed the amplification of fragments with lengths between 0.3 and $2 \mathrm{~Kb}$ that were sequenced for identification of the genomic marker adjacent region. For the first round: Primers RB1 and DegAlul, DegPstl, DegSacll and DegTaql (sequence 
detailed in Table I and in [25]) and cycling conditions $1 \mathrm{x}$ (95 $\left.{ }^{\circ} \mathrm{C}, 5 \mathrm{~min}\right), 20 x\left(95^{\circ} \mathrm{C}, 1 \mathrm{~min} ; 60^{\circ} \mathrm{C}, 1 \mathrm{~min} ; 72{ }^{\circ} \mathrm{C}, 3 \mathrm{~min}\right), 10 \mathrm{x}$ $\left(95^{\circ} \mathrm{C}, 1 \mathrm{~min} ; 40{ }^{\circ} \mathrm{C}, 1 \mathrm{~min} ; 72{ }^{\circ} \mathrm{C}, 3 \mathrm{~min}\right) ; 1 \times\left(72{ }^{\circ} \mathrm{C}, 10 \mathrm{~min}\right)$ were used. For the second round the primers were RB4 and Qo (sequence detailed in Table I and in [17]) and the cycling conditions: $1 \times\left(96{ }^{\circ} \mathrm{C}, 5 \mathrm{~min}\right) 35 \times\left(95^{\circ} \mathrm{C}, 1 \mathrm{~min} ; 60^{\circ} \mathrm{C}, 1 \mathrm{~min}\right.$; $\left.72^{\circ} \mathrm{C}, 3 \mathrm{~min}\right) 1 \times\left(72^{\circ} \mathrm{C}, 10 \mathrm{~min}\right)$.

Analysis of the genomic regions flanking the insertion The products amplified by inverse PCR or RESDA-PCR were separated by agarose gel electrophoresis. The fragments obtained were isolated with a gel extraction kit (Quiagen, Germany) and sequenced (Stabvida, Portugal). The resulted sequences were analyzed by comparison with Chlamydomonas genome database [31].

\section{Analysis of pigments}

Carotenoids and chlorophylls were extracted with $80 \%$ acetone. The separation and chromatographic analysis of pigments were preformed in a Merck Hitachi High-performance liquid chromatography (HPLC) equipped with a Diode-array detector as described by Young and coworkers [32], using a $\mathrm{RP}-18$ column and a flow rate of $1 \mathrm{ml} \mathrm{min}{ }^{-1}$. The mobile phase consisted of: solvent $A$, ethyl acetate; solvent $B$ acetonitrile/ water $(9: 1, v / v)$ and the gradient programme applied was: 0-16 $\min 0-60 \%$ A; $16-30 \min 60 \%$ A; $30-35 \min 100 \%$ B. Injection volume was $100 \mu$ l. Pigments detection was carried out at $450 \mathrm{~nm}$. Pigments standards were supplied by SIGMA or DHI (Hoersholm, Denmark).

\section{Quantitative Real-Time PCR (QPCR)}

Real time PCR was performed on a Mx3000P Multiplex Quantitative PCR System from Stratagene using the Brilliant SYBR Green QPCR Master Mix (Stratagene). Each determination was carried out in triplicate using genomic DNA as template and 10 pmoles of the indicated primers in a final volume of $25 \mu \mathrm{l}$. Cycling conditions were: $10 \mathrm{~min}$ at $95^{\circ} \mathrm{C}$ for activation of the hot start Taq polymerase and 40 cycles for the melting $\left(30 \mathrm{~s}\right.$ at $\left.95^{\circ} \mathrm{C}\right)$, annealing $\left(30 \mathrm{~s}\right.$ at $60^{\circ} \mathrm{C}$ ) and extension (30 s at $72{ }^{\circ} \mathrm{C}$ ). The fluorescence measurement was made at the end of the annealing step. A dissociation curve $\left(30 \mathrm{~s}\right.$ at $95^{\circ} \mathrm{C}$, $30 \mathrm{~s}$ at $55^{\circ} \mathrm{C}$ and $30 \mathrm{~s}$ at $95^{\circ} \mathrm{C}$ ) was applied at the end of the amplification reaction to check possible formation of dimmers.

\section{Results}

\section{Generation of insertional mutants}

Insertional mutants were obtained by nuclear transformation of Chlamydomonas reinhardtii, strain 704, with a 1800 bp lineal DNA fragment, which contains the paromomycin resistant AphVIII gene from Streptomyces rimosus under the control of the Hsp70A:RbcS2 promoters and the RbcS2 terminator region [24]. This cassette, obtained by the digestion of pSI103 with Notl and Kpnl restriction enzymes (Figure 1.1), was randomly integrated by non-homologous recombination into the nuclear genome of $C$. reinhardtii, causing disruption of nuclear genes and generating random mutants. About 2100 mutants were isolated at dim light in the presence of the antibiotic paromomycin and screened for light sensitivity, pigment deficiency and lack of zeaxanthin in response to high light stress phenotypes as described below. The mean transformation efficiency was about 270 transformants per $\mu \mathrm{g}$ of DNA. Mutants were maintained in TAP-agar plates in the presence of paromomycin to minimize gene silencing of the inserted DNA. The AphVIII cassette was chosen as selectable marker because its high level of expression has already been shown [23] and the selective antibiotic paromomycin lacks the mutagenic effect reported for bleomycin [14]. No more than $100 \mathrm{ng}$ of DNA per transformation were used in mutagenesis experiments since this small quantity of DNA is enough to ensure a good number of transformants minimizing the integration of multiple copies of the marker DNA, as has been set up by González-Ballester and coworkers [21]. Single integration is desirable to establish an unequivocal relation between the observed phenotype and the disrupted gene.

\section{Screening of insertional mutants sensitive to high light} and with altered pigment composition

Our objective was to identify tagged mutants with an altered composition of pigments, to gain more knowledge about the synthesis of chlorophylls and carotenoids in Chlamydomonas. Some of these mutants can be easily identified by direct observation, because if they have a great deficiency in pigments they will appear as white or pale yellow colonies. But those mutants which have a small pigment deficiency or lack any minor carotenoid will not show an obvious colour difference. To avoid loosing these partial pigment deficient transformants, we have designed a two steps screening strategy: In the first step we isolated a collection of light-sensitive mutants, whose pigment composition was systematically analysed by HPLC in the second step.

The first screening step was carried out exposing the insertional mutants to high light $\left(800 \mu \mathrm{E} \mathrm{m}^{-2} \mathrm{~s}^{-1}\right)$, as described in Screening of light sensitive and pigment deficient mutants. In this way we were able to select 14 light sensitive mutants among the 1200 paromomycin resistant mutants obtained. Two of these mutants were obviously deficient in pigments since they were practically white (mutant M2) or pale orange (mutant C13) in dim light and unable to live at standard light intensity. Mutant M2 practically lacks carotenoids and chlorophylls and mutant $\mathrm{C} 13$ has very low content of chlorophylls and slightly lower content of carotenoids than the control non-transformed cells. The chromatographic pigment spectra and the coloration of the colonies of these two mutants are shown in Figure 3 in comparison with the pigment profile of control cells.

The other 12 light-sensitive mutants were cultured in TAP medium at low light intensity, their carotenoids and chlorophyll content was determined by HPLC analysis, 
Vila et al. Genomics Discovery 2013,

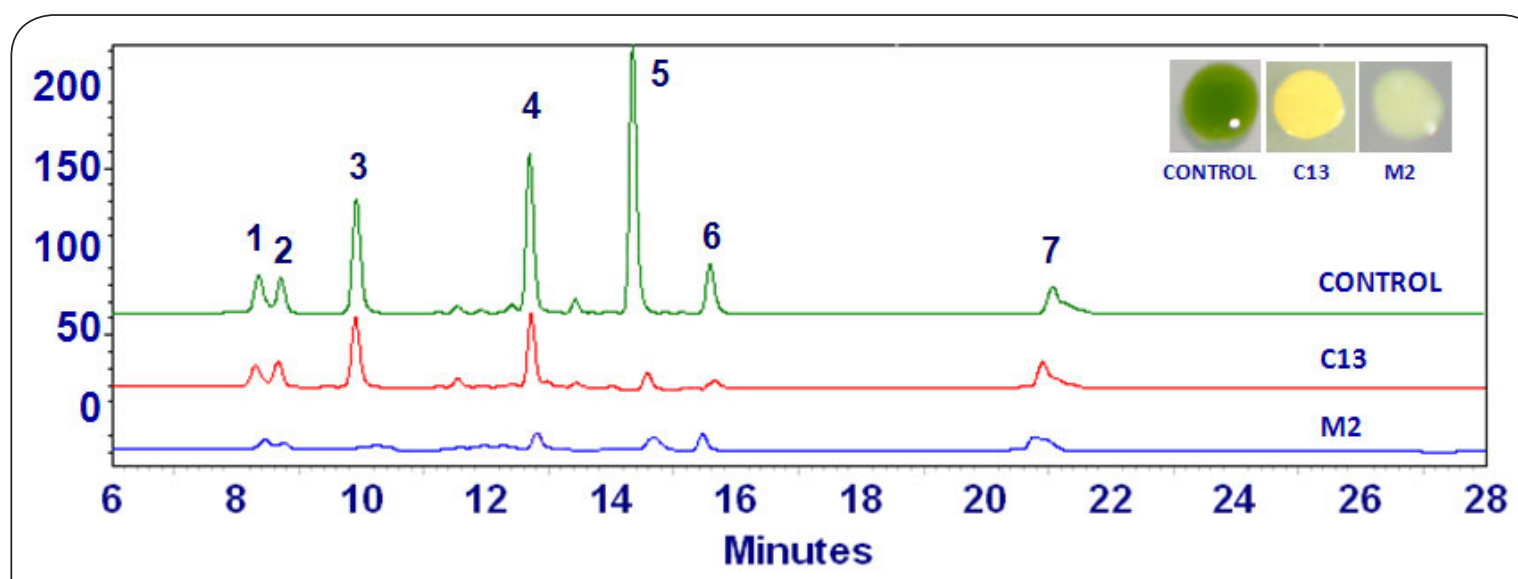

Figure 3. Analysis of pigment-deficient mutants. Pigment phenotype and HPLC-chromatograms registered at 450 $\mathrm{nm}$ for C13 and M2 mutants cultured at dim light and comparison with control Chlamydomonas cells cultured in the same conditions are shown. Peaks identification: Loroxanthin (1), Neoxanthin (2), Violaxanthin (3), Lutein (4), Chlorophyll b (5), Chlorophyll a (6), $\beta$-Carotene (7).

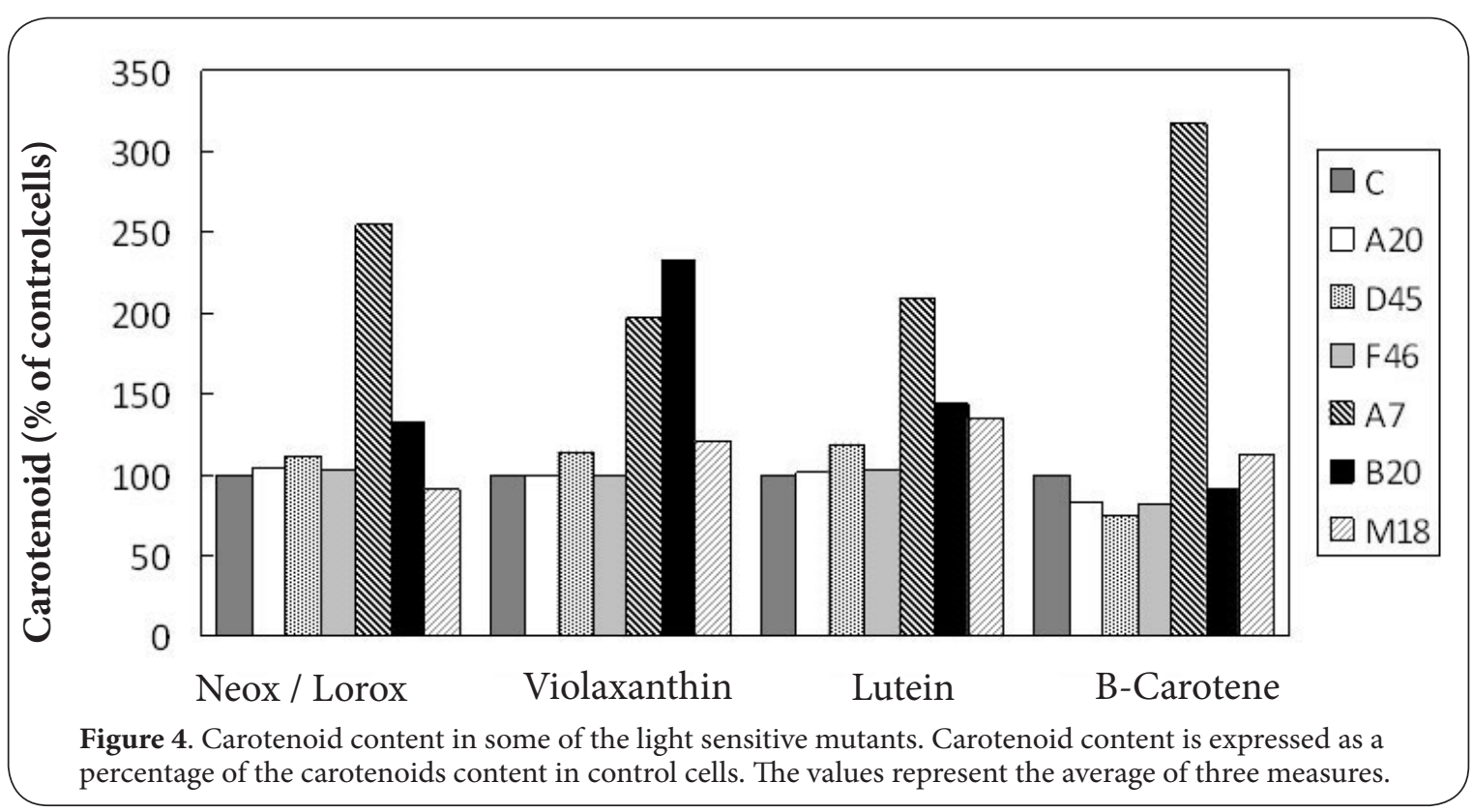

referred to the dry weight and expressed as the percentage over the corresponding carotenoid concentration in control cells. The carotenoids content of some of these mutants is shown in Figure 4. This rescreening allowed us to select two additional mutants that, beside the sensitivity to high light, had an altered pigment profile. Mutant B20 had very high content of the epoxidated carotenoid violaxanthin, which reached an intracellular level of $0.9 \mathrm{mg} \mathrm{g}^{-1} \mathrm{DW}, 2.5$ fold the level observed in control Chlamydomonas cells cultured in the same conditions. While mutant A7 had higher content of all the carotenoids, mainly of b-carotene, which was three fold the content of control culture, and violaxanthin, which content was more than two-fold the value in control cells. The other light sensitive mutants (A4, A20, D45, F46, M3, M4,
M5, M12, M17 and M18) had normal pigment composition, but the marker- gene insertion site was also studied in these transformants (Table II).

\section{Screening of insertional mutants with an altered response to high light stress}

The main short-time response in many higher plants and microalgae when transferred from low to high light intensity is the synthesis of zeaxanthin from violaxanthin through the xanthopyll cycle [33,34]. In Chlamydomonas this response to high light shifts is well documented [4]. The synthesis of zeaxanthin in Chlamydomonas cells after exposure to a high light stress [35] and other kind of stress conditions [36] has been previously reported. It has been demonstrated that this 
Vila et al. Genomics Discovery 2013,

http://www.hoajonline.com/journals/pdf/2052-7993-1-2.pdf

doi: $10.7243 / 2052-7993-1-2$

Table II. Analysis of the genomic regions flanking the insertion of the marker gene for some of the obtained mutants.

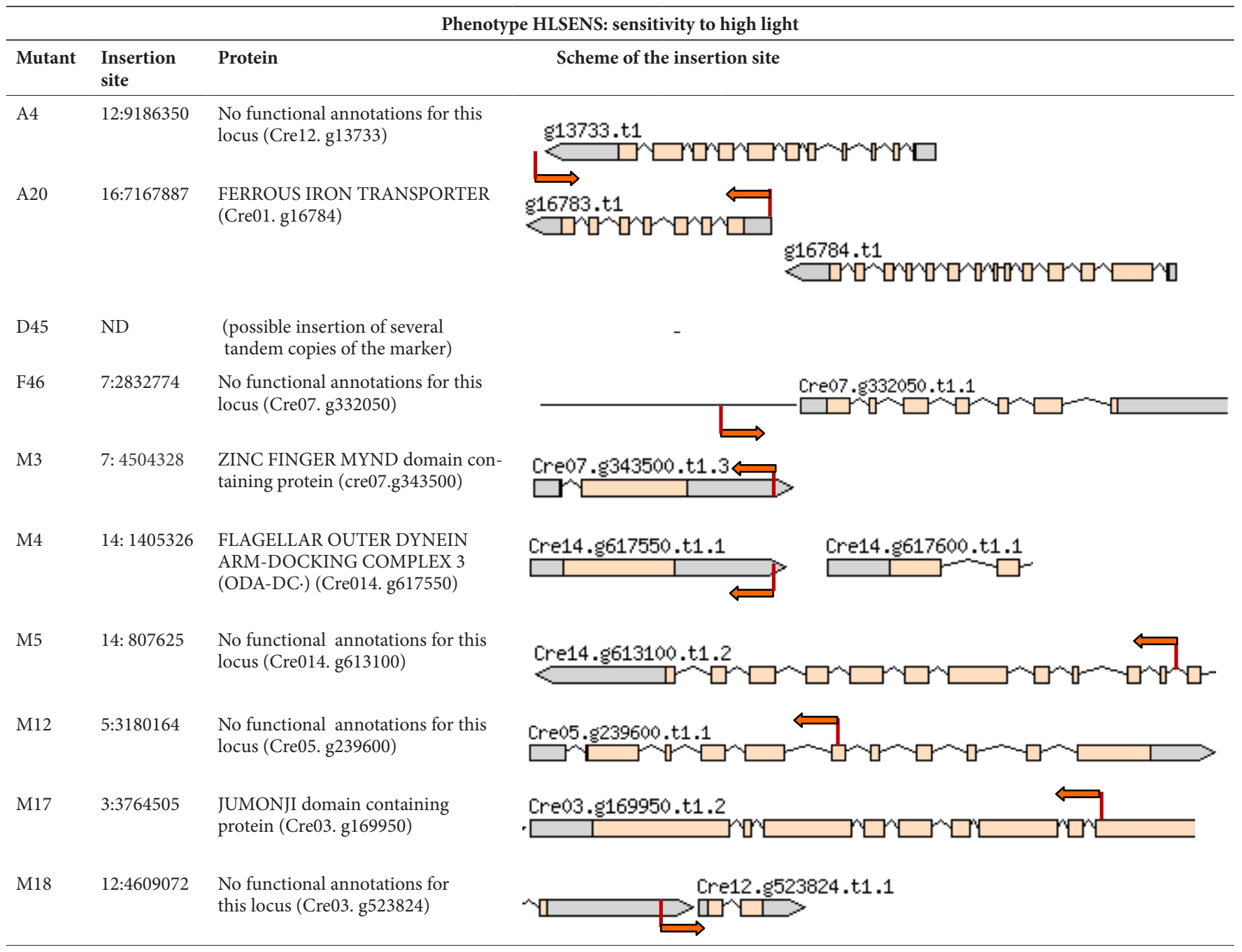

Phenotype PIGMENTS: Altered pigment composition

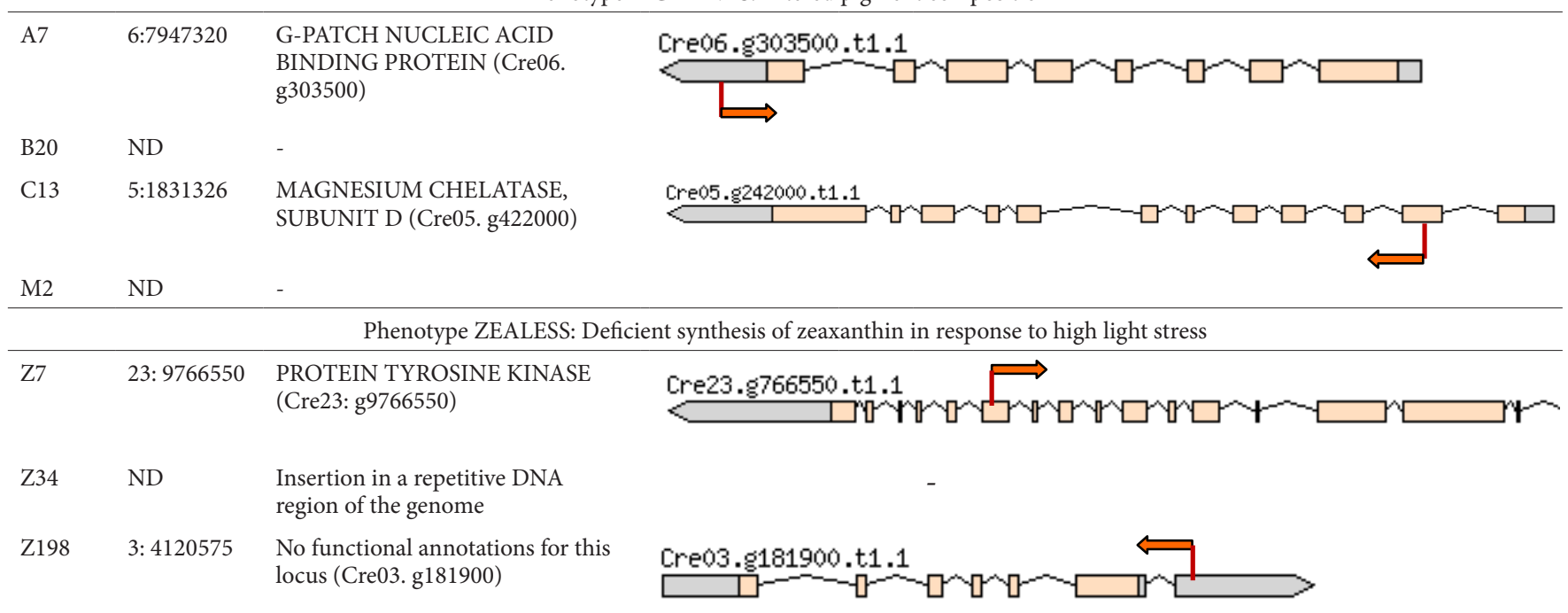

Localization of the marker insertion site and description of the protein encoded by the interrupted gene, when available, are shown. Dark grey: untranslated regions. Light grey: exons. Lines: introns. The Arrows indicate the point and the sense of the insertions. In the insertion site column the chromosome: nucleotide position for the insertion is indicated. 
Vila et al. Genomics Discovery 2013,

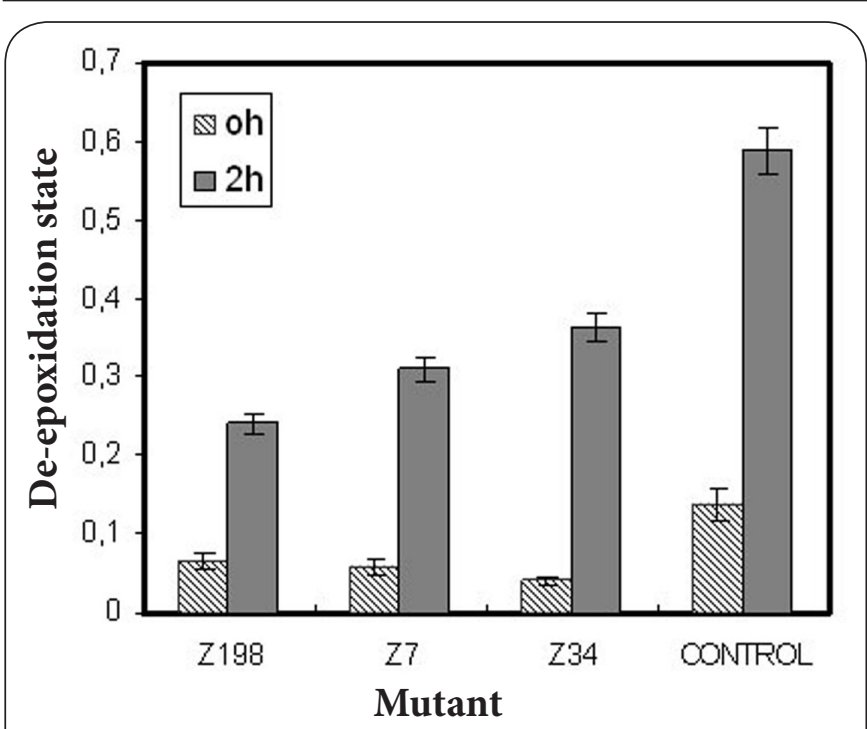

Figure 5. De-epoxidation state of the xanthophyll cycle in dark pretreated Control and ZEALESS mutants of Chlamydomonas reinhardtii. Dark pretreated cells were transferred to high light $\left(800 \mu \mathrm{E} \mathrm{m}^{-2} \mathrm{~s}^{-1}\right)$ and the deepoxidation state, expressed as the ratio [(ant + zea) / (ant + zea + viol)], was determined after $2 \mathrm{~h}$.

zeaxanthin is produced from violaxanthin via the xanthophyll cycle [33], but neither the enzyme nor the gene encoding this putative violaxanthin de-epoxidase (VDE) has been identified yet in Chlamydomonas. In the sequenced genome of this chlorophyte no orthologues to plant or other algal VDE genes have been identified [37].

About 900 insertional mutants were obtained and screened to check their response when submitted to high light stress. The mutants were picked up and cultured in $5 \mathrm{ml} \mathrm{TAP} \mathrm{liquid}$ media with paromomycin $15 \mathrm{\mu g} \mathrm{ml}^{-1}$ until the exponential phase of growth, then they were transferred to dark, where they stayed for $24 \mathrm{~h}$. After the dark pretreatment the cultures were submitted to high light intensity $\left(800 \mu \mathrm{E} \mathrm{m}^{-2} \mathrm{~s}^{-1}\right)$. The ability of the stressed mutants to epoxidise violaxanthin producing the quenching xanthophylls antheraxanthin and zeaxanthin, expressed as the de-epoxidised state, was determined after $2 \mathrm{~h}$ of treatment and compared with that of control $C$. reinhardtii cells submitted to the same conditions. This allowed us to isolate 3 mutants (Z7, Z34 and Z198) in which the de-epoxidation state after the high light shock was significantly lower than the de-epoxidation state of control cells in the same stress conditions (Figure 5).

The standard intracellular level of the quenching xanthophylls, zeaxanthin and antheraxanthin, is very low in the dark. Their concentration was about $14 \%$ of the total cycle xanthophylls pool in control cells and between 4 and $6 \%$ in the studied mutants. Under high light stress, the deepoxidation state increases until 0.58 in control cells, while the de-epoxidation state in the selected mutants reaches values between 0.24 and 0.32 . The lowest de-epoxidation state under high light stress was observed for mutant Z198, with a value of 0.24 , which is less than half the de-epoxidation state of control cells under the same high light stress conditions.

In Figure 6, the time course evolution of the xanthophyll cycle components for control Chlamydomonas cells and for the three selected zeaxanthin deficient mutants (ZEALESS mutants) submitted to light stress is plotted. After $24 \mathrm{~h}$ of dark pretreatment the cultures were exposed to high light intensity $\left(800 \mu \mathrm{E} \mathrm{m}^{-2} \mathrm{~s}^{-1}\right)$ for 6 hours. In these conditions, the zeaxanthin intracellular concentration in the mutants $Z 34$ and $\mathrm{Z7}$, was about half the concentration in control untransformed cells, while in mutant Z198 the zeaxanthin content did not even reach one fourth the zeaxanthin level of control cells. The decrease in violaxanthin content was much slower and minor in the mutants than in the control. On the contrary, the production of the intermediate antheraxanthin is similar in control and mutant cells, being only slightly lower in the mutant Z198. This could suggest that both sequential steps involved in violaxanthin de-epoxidation to antheraxanthin and zeaxanthin are differentially regulated. Although in the three mutants production of zeaxanthin and violaxanthin de-epoxidation was partially inhibited, no mutant with total lack of de-epoxidation activity was obtained.

\section{Identification of the genomic regions flanking the insertion}

To establish an unequivocal relationship between the observed phenotype and the affected gene it is necessary to ensure a unique insertion event. The DNA was kept to the minimum in the transformation experiments and the number of copies of the tag DNA was checked by Real Time PCR using the singlecopy gene Nitrate Reductase 1 (Nia1) as reference. This method has been previously validated by comparison with southern blot analysis [21]. The number of integrations was calculated using the delta Ct method [38] and specific primers of very similar efficiencies for AphVIII and Nia 1 (Table I). Efficiencies of the primers were previously determined [21]. We found that practically all of the mutants analyzed had a single copy of the tag DNA in their genomes. The only exception was mutant D45 that seems to have several copies of the marker gene. Two different methods were used to determine the genomic DNA flanking the inserted marker gene: RESDA-PCR [25] or inverse PCR over ligation [26].

RESDA-PCR basically involves using specific primers for the marker gene together with degenerated primers, designed on the basis of the presence of frequent restriction sites randomly distributed in the microalgal genome [25]. A schematic representation of the RESDA strategy with indication of the annealing sites for the primers is shown in Figure 1.2. This method allowed the amplification of the flanking region in 3 of the 17 mutants analysed. Inverse PCR over ligation is based on the fact that the chosen restriction enzyme, which cuts once inside the AphVIII gene, will also cut outside the insert, in the flanking genomic regions. On the basis of this 
Vila et al. Genomics Discovery 2013,

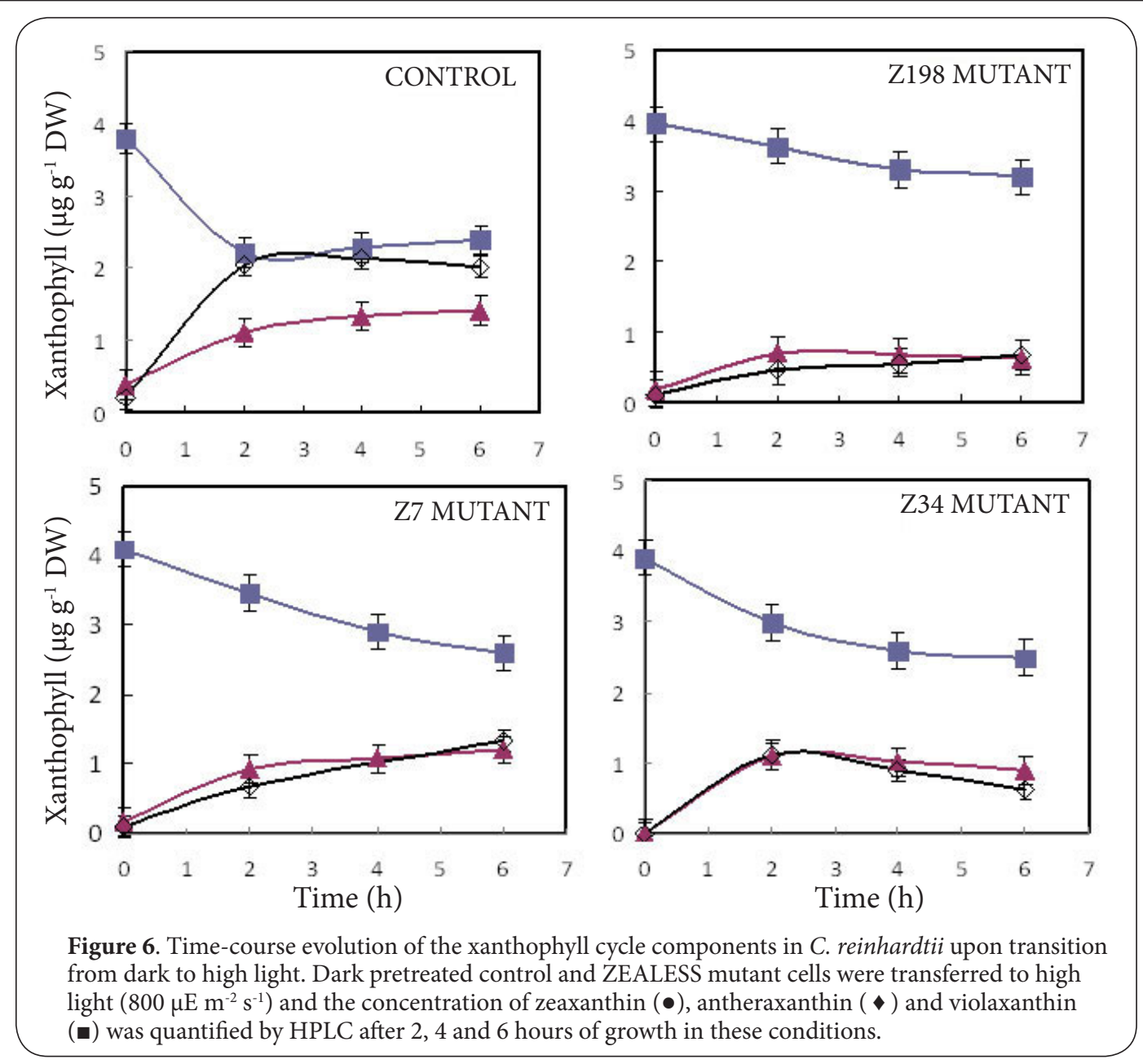

hypothesis the genomic DNA of the mutant is digested with the chosen restrictase and ligated. The ligation resulted is used as a template for the inverse PCR. The approximate situation of the primers designed to amplify the genomic region flanking the insertion is shown in Figure 1.1. This method allowed the identification of the flanking region in other 12 of the 17 mutants analysed. In two mutants (B20 and M2) no amplification was possible by either of the approaches used and the flanking region could not be identified. The sequences of the region adjacent to the insertion were compared with the genome sequence of Chlamydomonas [31].

\section{Identification of the genes responsible for the observed phenotype}

The sequences of the genomic regions flanking the insert allowed the identification of the gene disrupted by integration of the marker AphVIII gene. All the sequences obtained by amplification from the 13 mutants successfully analyzed, included a short fragment homologous to the 3'UTR region of $R b c S 2$ located in chromosome 2 , which confirmed specificity of the amplification, and a fragment that showed very high homology with the genome of Chlamydomonas. These fragments were compared with the latest version of the Chlamydomonas genome database at the joint genome center [31] by the BLAST tool. The insertion site and the protein encoded by the interrupted gene, when available, are shown in Table II. In four of the mutants studied, identification of the gene affected by the integration was not possible. In mutants B20 and M2 several attempts did not yield any amplification. This could mean that the insertion has taken place in a region of low accessibility or that silencing epigenetic phenomena that modify the structure of the marker gene are interfering with the alignment of primers during PCR amplifications as proposed by González-Ballester and coworkers [21]. In mutant $\mathrm{D} 45$, predicted region coincides with the region of the chromosome 8, where is located the promoter of the Hsp70A gene and within the region of chromosome 2 corresponding to the $R b c S 2$ promoter, which are part of the same insertional cassette, indicating the possible insertion of several tandem copies of the marker gene, as was already predicted when determining the number of integrations. In mutant Z34 the amplified DNA fragment showed $100 \%$ homology with several regions of the genome located in different chromosomes, so the region affected by the integration could not be identified in 
Vila et al. Genomics Discovery 2013,

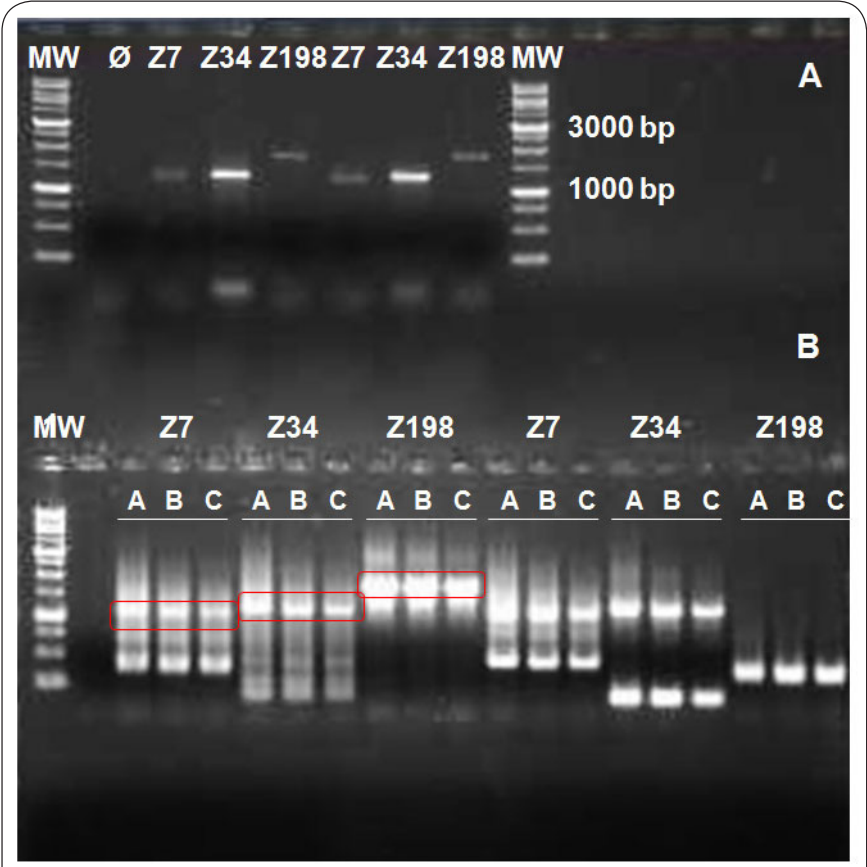

Figure 7. Agarose gel analysis of the inverse PCR products obtained for 3 insertional mutants. Genomic DNA of transformants Z34, Z198 and Z7 was isolated, digested and ligated as described in the materials and methods section. The resulting ligations were used as template for nested PCR. In the first amplification round (A) RB1 and LB1 primers were used with the resulting ligation as template. In the second round (B) primers RB4 and LB4 were used for reamplification of different dilutions of the PCR products obtained in the first round. Lines 1 and 2: $1 \mathrm{~Kb}$ ladder DNA marker; $\mathrm{a}, \mathrm{b}$ and $\mathrm{c}$ correspond to dilutions $1: 1,1: 10,1: 100$, respectively.

this case because the marker gene has probably been inserted in a repetitive region of the genome. In Chlamydomonas more than $20 \%$ of the genome is repetitive DNA [1].

Six of the disrupted genes in the analysed mutants encoded predicted proteins of unkown funtions, while the other 7 genes encoded known proteins with a great variety of functions. Table II shows the resume of the genes affected in the 13 mutants successfully analysed. Among the light-sensitive mutants we found mutants affected in the function and assembly of the flagella, such as the mutant M4, in which the tag DNA is inserted at the beginning of the gene encoding the subunit 3 of the Flagellar Outer Dynein arm-docking complex subunit 3 (oda-dc 3 ). We also found mutants affected in nucleic acid binding proteins with known conserved domains, such as the Jumonji (M17) or the Mynd Zinc Finger (M3), involved in regulation of the transcription. A mutant affected in the D-Tyrosil-tRNA (Tyr) Deacylase (A4), an editing enzyme that removes $D$ - amino acids from mischarged tRNAs. And mutants affected in transduction pathways, such as the Putative Mitocondrial GTPase protein mutant (A20).

Among the pigment deficient mutants, $\mathrm{C} 13$ has an insertion in the gene encoding the D Subunit of Mg-Chelatase, which catalyzes the first committed step of chlorophyll synthesis, the insertion of $\mathrm{Mg}^{2+}$ into the protoporphyrin ring to yield Mg-protoporphyrin IX [39], and is a key regulatory point in the chlorophyll biosynthetic pathway [40]. In A7 mutant the tag is inserted in a putative regulatory protein, the nucleic acid binding protein, which contains the D111/G-patch dominium, a motif found in many Ribose Nucleic Acid (RNA) Binding proteins.

For mutant $\mathrm{C} 13$ a detailed study of the insertion site was carried out. An additional set of primers were designed to identify the genomic region at the 5 'end of the inserted cassette (Figure 1) and it was revealed that in this mutant the insertion was clean without deletions, and that the tag DNA was placed in the third intron of the interrupted gene, causing the synthesis of a truncated and non-functional version of the $\mathrm{Mg}$-chelatase subunit D. A phenotype similar to that of mutant $\mathrm{C} 13$ has been found in other $C$. reinhardtii mutants affected in the Mg-chelatase subunits $\mathrm{H}$ [41] and $\mathrm{M}$ [42].

The last group of mutants, deficient in their response to high light stress, are unable to synthetize normal quantities of zeaxanthin when shifted to high light conditions. The gene affected by the insertion in mutant Z198 corresponds to a predicted protein of unknown function, while in mutant $\mathrm{Z7}$, the tag is inserted in a gene encoding a protein Tyrosine Kinase, involved in signal transduction pathway. In Z34 it was not possible to identify the insertion site, the DNA sequence preceding the marker resulted to hit with multiple zones of the genome in all cases with homologies near $100 \%$, indicating that it was a repetitive region of the genome. The predicted protein in mutant Z198 is a hypothetical protein with 218 residues which has also been found in other related algae such as Volvox carteri and Micromonas, it has certain homology with bacterial metal responsive transcripcional regulator factors of the MerR family. Detailed analysis of the genomic region flanking the marker gene in these three mutants is presented in Figure 7.

\section{Discussion}

Reverse genetic approaches, such as RNA interference [43] or PCR, exploring of tagged mutant collections [14] allow the knock out of specific known genes and have helped to the functional characterization of a good number of genes in Chlamydomonas. However, insertional mutagenesis is the best approach to identify uncharacterized genes related to a certain phenotype. The latest version of the nuclear genome of Chlamydomonas, ver 5.3, was released in January 2012. It comprises $111 \mathrm{Mb}$ arranged in 17 linkage groups (chromosomes) and 37 additional unmapped scaffolds, with about 17728 protein encoding loci. Some of these loci encode alternate transcript making a total of 19529 protein coding transcripts, however there is a large number of predicted proteins of unknown function, confirming that an effort is necessary to understand the function of genes which cannot be assigned by sequence comparison [1]. 
In our analysis most of the transformants (94\%) had a single AphVIII insertion. Cloning, sequencing and aligment of the DNA fragments, amplified by RESDA or inverse PCR in each transformant, with the Chlamydomonas database has allowed the identification of the region adjacent to the insertion in most of the mutants studied. We observed that in $77 \%$ of the transformants analysed, the insertion took place in intragenic regions. This rate is similar to that observed by Dent and coworkers [20] and González-Ballester and coworkers [21] in functional genomic studies of photosynthesis and the regulation of nitrate assimilation, respectively. In all cases the marker insertion has occurred within a predicted gene or very near one, so identification of the gene responsible for the observed phenotype, has been done considering that the gene interrupted is the most probable responsible of the observed phenotype. If integration of the tag gene takes place with big genome deletions of upto $20 \mathrm{~Kb}$, as has been reported in some insertional mutagenesis experiments, other genes placed near the insertion site could also be affected and be responsible for the observed phenotype, but since we do not have the evidence of the deleted genomic area in most of the mutants, this possibility has not been considered here. Only in mutant $\mathrm{C} 13$ the flanking region at both sides of the insertion have been amplified and identified, revealing that the tag insertion took place without a deleted nucleotide.

To identify the region flanking the marker inserted, both the RESDA-PCR [25] and inverse PCR after digestion with an enzyme having a unique restriction site in the marker gene, [26] were successfully used. Most of the mutants were solved by inverse PCR and those mutants recalcitrant to inverse PCR were successfully solved by RESDA. Only 4 mutants remained unresolved, probably due to the insertion of several concatamerized copies of the marker gene, as happens in mutant D45; due to insertion in a genome repetitive element, as observed in mutant Z34; or because of insertion in a difficult region of the genome, or modifications of the marker gene after the insertion that make difficult the aligment of primers during PCR, as proposed by González-Ballester and coworkers [25].

Almost half of the mutants ( $46 \%$ ) had insertions in genome loci with unknown functions. Among disrupted genes with a known function we found genes involved in a great diversity of functions, from flagella motion to regulatory or signal transduction processes, suggesting that the sensitivity to high light and the synthesis of pigments are complex and very regulated processes and that a large number of mutants should be generated to saturate the genes encoding proteins involved in these processes. Here we describe the generation and characterization of 13 of the obtained mutants, as a first step to the generation of a large collection of mutants which will be mainly focussed on mutants unable to synthetize zeaxanthin in response to high light stress. This strategy has already allowed the isolation of Z7, Z34 and Z198 mutants, in which the xanthophyll cycle is partially inhibited. The de-epoxidation state in these mutants is less than half the de-epoxidation state in control cells cultured in the same conditions, due to a big decrease in the zeaxanthin synthesis and in the de-epoxidation of violaxanthin. Although neither mutant $\mathrm{Z7}$, which is affected in a protein with homology to protein tyrosine kinase, nor Z198, which is affected in a gene which encodes a predicted protein of unknown function, are VDE mutants, it is clear that they must be affected in regulatory or signalling processes very related to violaxanthin de-epoxidase.

\section{Competing interests}

The authors declare that they have no competing interests.

\section{Authors' contributions}

M. Vila has acquired some experimental data, contributed to data analysis and to writing of the manuscript.

E. Díaz-Santos and M. de la Vega have acquired experimental data and performed statistical analysis. I. Couso has made critical revision of the maunsucript. R. León has conceived and designed the research, has analyzed obtained data and written the manuscript.

\section{Acknowledgement}

This study was supported by a grant from the Andalusian government (P09-CVI-5053 and BIO-214). We gratefully acknowledge Prof. E. Fernández and his group from the University of Córdoba for generous assistance and valuable help with RESDA PCR.

\section{Publication history}

Editor: YunguiYang, Beijing Institute of Genomics, China. EIC: Prof. Viroj Wiwanitkit, Hainan Medical University, China. Received: 01-Jul-2013 Revised: 24-Jul-2013

Accepted: 02-Aug-2013 Published: 19-Aug-2013

\section{References}

1. Merchant SS, Prochnik SE, Vallon O, Harris EH, Karpowicz SJ, Witman GB, Terry A, Salamov A, Fritz-Laylin LK, Marechal-Drouard L et al. The Chlamydomonas genome reveals the evolution of key animal and plant functions. Science. 2007; 318:245-50. | Article | PubMed Abstract | PubMed Full Text

2. Harris EH: Second edition, CA: D. Stern, G. Witman (eds). Academic Press, San Diego, Chlamydomonas sourcebook: Introduction to Chlamydomonas and Its Laboratory Use. Vol 1. 2009. | Book

3. Mendez-Alvarez S, Leisinger $U$ and Eggen RI. Adaptive responses in Chlamydomonas reinhardtii. Int Microbiol. 1999; 2:15-22. I PubMed

4. Niyogi KK. PHOTOPROTECTION REVISITED: Genetic and Molecular Approaches. Annu Rev Plant Physiol Plant Mol Biol. 1999; 50:333-359. | Article I PubMed

5. Grossman AR, Lohr M and Im CS. Chlamydomonas reinhardtii in the landscape of pigments. Annu Rev Genet. 2004; 38:119-73. | Article | PubMed

6. Gonzalez-Ballester D, Pootakham W, Mus F, Yang W, Catalanotti C, Magneschi L, de Montaigu A, Higuera JJ, Prior M, Galvan A, Fernandez $E$ and Grossman AR. Reverse genetics in Chlamydomonas: a platform for isolating insertional mutants. Plant Methods. 2011; 7:24. | Article | PubMed Abstract | PubMed Full Text

7. Reyon D, Kirkpatrick JR, Sander JD, Zhang F, Voytas DF, Joung JK, Dobbs $D$ and Coffman CR. ZFNGenome: a comprehensive resource for locating zinc finger nuclease target sites in model organisms. BMC Genomics. 2011; 12:83. | Article | PubMed Abstract | PubMed Full Text

8. McCallum CM, Comai L, Greene EA and Henikoff S. Targeting induced local lesions IN genomes (TILLING) for plant functional genomics. Plant 
Vila et al. Genomics Discovery 2013,

http://www.hoajonline.com/journals/pdf/2052-7993-1-2.pdf

doi: $10.7243 / 2052-7993-1-2$

Physiol. 2000; 123:439-42. | Article | PubMed Abstract | PubMed Full $\underline{\text { Text }}$

9. Till BJ, Reynolds SH, Greene EA, Codomo CA, Enns LC, Johnson JE, Burtner C, Odden AR, Young K, Taylor NE, Henikoff JG, Comai L and Henikoff S. Large-scale discovery of induced point mutations with high-throughput TILLING. Genome Res. 2003; 13:524-30. | Article | PubMed Abstract | PubMed Full Text

10. Gilchrist $E$ and Haughn G. Reverse genetics techniques: engineering loss and gain of gene function in plants. Brief Funct Genomics. 2010; 9:10310. | Article | PubMed

11. Molnar A, Bassett A, Thuenemann E, Schwach F, Karkare S, Ossowski S, Weigel $D$ and Baulcombe $D$. Highly specific gene silencing by artificial microRNAs in the unicellular alga Chlamydomonas reinhardtii. Plant J. 2009; 58:165-74. | Article | PubMed

12. Zhao $T$, Wang $W$, Bai $X$ and Qi Y. Gene silencing by artificial microRNAs in Chlamydomonas. Plant J. 2009; 58:157-64. | Article | PubMed

13. Schroda M. RNA silencing in Chlamydomonas: mechanisms and tools. Curr Genet. 2006; 49:69-84. | Article | PubMed

14. Galvan A, Gonzalez-Ballester D and Fernandez E. Insertional mutagenesis as a tool to study genes/functions in Chlamydomonas. Adv Exp Med Biol. 2007; 616:77-89. | Article | PubMed

15. Tam LW and Lefebvre PA. Cloning of flagellar genes in Chlamydomonas reinhardtii by DNA insertional mutagenesis. Genetics. 1993; 135:375-84. | Article | PubMed Abstract | PubMed Full Text

16. Pazour GJ, Sineshchekov OA and Witman GB. Mutational analysis of the phototransduction pathway of Chlamydomonas reinhardtii. J Cell Biol. 1995; 131:427-40. | Pdf | PubMed Abstract | PubMed Full Text

17. Pazour GJ and Witman GB. Forward and reverse genetic analysis of microtubule motors in Chlamydomonas. Methods. 2000; 22:285-98. | Article | PubMed

18. Yoshioka S, Taniguchi F, Miura K, Inoue T, Yamano T and Fukuzawa H. The novel Myb transcription factor LCR1 regulates the CO2-responsive gene Cah1, encoding a periplasmic carbonic anhydrase in Chlamydomonas reinhardtii. Plant Cell. 2004; 16:1466-77. | Article | PubMed Abstract | PubMed Full Text

19. Posewitz MC, Smolinski SL, Kanakagiri S, Melis A, Seibert M and Ghirardi $\mathrm{ML}$. Hydrogen photoproduction is attenuated by disruption of an isoamylase gene in Chlamydomonas reinhardtii. Plant Cell. 2004; 16:2151-63. | Article | PubMed Abstract | PubMed Full Text

20. Dent RM, Haglund CM, Chin BL, Kobayashi MC and Niyogi KK. Functional genomics of eukaryotic photosynthesis using insertional mutagenesis of Chlamydomonas reinhardtii. Plant Physiol. 2005; 137:545-56. | Article | PubMed Abstract | PubMed Full Text

21. Gonzalez-Ballester D, de Montaigu A, Higuera JJ, Galvan A and Fernandez E. Functional genomics of the regulation of the nitrate assimilation pathway in Chlamydomonas. Plant Physiol. 2005; 137:522-33. | Article | PubMed Abstract I PubMed Full Text

22. Pollock SV, Pootakham W, Shibagaki N, Moseley JL and Grossman AR. Insights into the acclimation of Chlamydomonas reinhardtii to sulfur deprivation. Photosynth Res. 2005; 86:475-89. | Article | PubMed

23. Lumbreras $V$, Stevens DR and Purton S. Efficient foreign gene expression in Chlamydomonas reinhardtii mediated by an endogenous intron. Plant J. 1998; 14: 441-447. | Article

24. Sizova I, Fuhrmann M and Hegemann P. A Streptomyces rimosus aphVIII gene coding for a new type phosphotransferase provides stable antibiotic resistance to Chlamydomonas reinhardtii. Gene. 2001; 277:221-9. | Article | PubMed

25. Gonzalez-Ballester D, de Montaigu A, Galvan A and Fernandez E. Restriction enzyme site-directed amplification PCR: a tool to identify regions flanking a marker DNA. Anal Biochem. 2005; 340:330-5. | Article I PubMed

26. de Montaigu A, Sanz-Luque E, Macias MI, Galvan A and Fernandez E. Transcriptional regulation of CDP1 and CYG56 is required for proper NH4+ sensing in Chlamydomonas. J Exp Bot. 2011; 62:1425-37. | Article I PubMed

27. Loppes R, Radoux M, Ohresser MC and Matagne RF. Transcriptional regulation of the Nia1 gene encoding nitrate reductase in Chlamydomonas reinhardtii: effects of various environmental factors on the expression of a reporter gene under the control of the Nia1 promoter. Plant Mol Biol. 1999; 41:701-11. | Article | PubMed

28. Sambrook J, Fritsch EF and Maniatis T. Cold Spring Harbor Labortory Press Cold Spring Harbor. Molecular cloning: A laboratory manual, 2nd edn. 1989. | Book

29. Kindle KL. High-frequency nuclear transformation of Chlamydomonas reinhardtii. Proc Natl Acad Sci U S A. 1990; 87:1228-32. | Article | PubMed Abstract | PubMed Full Text

30. Liu YG and Whittier RF. Thermal asymmetric interlaced PCR: automatable amplification and sequencing of insert end fragments from P1 and YAC clones for chromosome walking. Genomics. 1995; 25:674-81. | Pdf | PubMed

31. University of California Regents. Joint Genome Institute. 2006. I Website

32. Young A, Orset $S$ and Tsavalos A. Methods for carotenoid analysis. In Pessarakli M (Ed), Marcel Dekker, New York. Handbook of Photosynthesis. 1997; 597-622. | Pdf

33. Jahns P, Latowski D and Strzalka K. Mechanism and regulation of the violaxanthin cycle: the role of antenna proteins and membrane lipids. Biochim Biophys Acta. 2009; 1787:3-14. | Article | PubMed

34. Li Z, Wakao S, Fischer BB and Niyogi KK. Sensing and responding to excess light. Annu Rev Plant Biol. 2009; 60:239-60. | Article | PubMed

35. Couso I, Vila M, Vigara J, Vargas MA, Rodríguez H and León R. Synthesis of carotenoids and regulation of the carotenoid biosynthesis pathway in response to high light stress in the unicellular microalga Chlamydomonas reinhardtii. Eur. J. Phycol 2012, 47 (3): 223-232. | Article

36. Anwaruzzaman M, Chin BL, Li XP, Lohr M, Martinez DA and Niyogi KK. Genomic analysis of mutants affecting xanthophyll biosynthesis and regulation of photosynthetic light harvesting in Chlamydomonas reinhardtii. Photosynth Res. 2004; 82:265-76. | Article | PubMed

37. Lohr M, Im CS and Grossman AR. Genome-based examination of chlorophyll and carotenoid biosynthesis in Chlamydomonas reinhardtii. Plant Physiol. 2005; 138:490-515. | Article | PubMed Abstract | PubMed Full Text

38. Ingham DJ, Beer S, Money S and Hansen G. Quantitative real-time PCR assay for determining transgene copy number in transformed plants. Biotechniques. 2001; 31:132-4, 136-40. | PubMed

39. Walker $\mathrm{CJ}$ and Willows RD. Mechanism and regulation of Mg-chelatase. Biochem J. 1997; 327 ( Pt 2):321-33. | Article | PubMed Abstract | PubMed Full Text

40. Stenbaek A and Jensen PE. Redox regulation of chlorophyll biosynthesis. Phytochemistry. 2010; 71:853-9. I Article | PubMed

41. Chekounova E, Voronetskaya V, Papenbrock J, Grimm B and Beck CF. Characterization of Chlamydomonas mutants defective in the $\mathrm{H}$ subunit of Mg-chelatase. Mol Genet Genomics. 2001; 266:363-73. | PubMed

42. Meinecke L, Alawady A, Schroda M, Willows R, Kobayashi MC, Niyogi KK, Grimm B and Beck CF. Chlorophyll-deficient mutants of Chlamydomonas reinhardtii that accumulate magnesium protoporphyrin IX. Plant Mol Biol. 2010; 72:643-58. | Article | PubMed Abstract | PubMed Full Text

43. Molnar A, Schwach F, Studholme DJ, Thuenemann EC and Baulcombe DC. miRNAs control gene expression in the single-cell alga Chlamydomonas reinhardtii. Nature. 2007; 447:1126-9. | Article | PubMed

\section{Citation:}

Vila M, Díaz-Santos E, de la Vega M, Couso I and León R. Isolation and characterization of pigment deficient insertional mutants in the chlorophyte Chlamydomonas reinhardtii. Genomics Discov. 2013; 1:2.

http://dx.doi.org/10.7243/2052-7993-1-2 